\title{
SISTEM PENJAMINAN MUTU PERGURUAN TINGGI (SPM-PT) DI FAKULTAS TARBIYAH DAN KEGURUAN UIN SUNAN KALIJAGA YOGYAKARTA
}

\author{
Mochamad Nurhuda \\ Institut Agama Islam Tribakti Kediri \\ e-mail: huddaaa87@gmail.com
}

\begin{abstract}
This paper seeks to illustrate the implementation of Quality Assurance System of Higher Education (SPM-PT) in the Faculty of Tarbiyah and Teacher Training UIN Sunan Kalijaga Yogyakarta, with the problem of why the quality targets in the Faculty of Tarbiyah and Teacher Training UIN Sunan Kalijaga have not been achieved and how the implementation of university quality assurance system at the Faculty of Tarbiyah and Teacher Training UIN Sunan Kalijaga. Quality assurance of higher education in universities is the process of implementing and fulfilling the standard of management and higher education consistently and continuously, so that stakeholders (students, parents, the world of work, government, lecturers, support staff, and other interested parties) get satisfaction.
\end{abstract}

Tulisan ini berusaha menggambarkan implementasi Sistem Penjaminan Mutu Perguruan Tinggi (SPM-PT) di Fakultas Tarbiyah dan Keguruan UIN Sunan Kalijaga Yogyakarta, dengan rumusan masalah mengapa target mutu di Fakultas Tarbiyah dan Keguruan UIN Sunan Kalijaga belum tercapai dan bagaimana pelaksanaan sistem penjaminan mutu perguruan tinggi pada Fakultas Tarbiyah dan Keguruan UIN Sunan Kalijaga. Penjaminan mutu perguruan tinggi di perguruan tinggi adalah proses penerapan dan pemenuhan standar mutu pengelolaan dan pendidikan tinggi secara konsisten dan berkelanjutan, sehingga stakeholder (mahasiswa, orang tua, dunia kerja, pemerintah, dosen, tenaga penunjang, serta pihak lain yang berkepentingaan) memperoleh kepuasan. 
Keywords: Quality Assurance System of Higher Education (SPM-PT), Faculty of Tarbiyah and Teacher Training.

\section{Pendahuluan}

Budaya peningkatan mutu pendidikan akan dapat dilaksanakan dengan baik bila lembaga pendidikan terbiasa melaksanakan Sistem Penjaminan Mutu Pendidikan (SPMP) dalam implementasi manajemen di sekolah atau madrasah. Instrumen utama dalam pelaksanaan SPMP adalah Evaluasi Diri Sekolah (EDS). Dalam implementasinya, EDS akan ditindaklanjuti dengan program Monitoring Sekolah oleh Pemerintah Daerah (MSPD) yang dilaksanakan oleh para Pengawas Pendidikan. MSPD merupakan instrumen utama Evaluasi Diri Kota/Kabupaten (EDK) sebagai dasar penyusunan program peningkatan mutu pendidikan di wilayah tersebut. Dengan demikian, SPMP yang diimplementasikan dalam kegiatan EDS akan menjadi komponen utama dalam lingkup implementasi Manajemen Berbasis Sekolah (MBS) sebagai upaya pembudayaan peningkatan mutu pendidikan di sekolah yang berkelanjutan.

Penyelenggaraan pendidikan merupakan realisasi dari salah satu didirikannya negara Indonesia, yaitu mencerdaskan kehidupan bangsa. Dalam upaya mencerdaskan kehidupan itulah diselenggarakan pendidikan nasional yang berdasarkan pancasila sebagai pandangan hidup bangsa. Dalam undang-undang sistem pendidikan nasional tersimpan visi yaitu terwujudnya sistem pendidikan sebagai pranata sosial yang kuat dan berwibawa 
untuk memperdayakan semua warga negara Indonesia berkembang menjadi manusia yang berkualitas sehingga mampu dan proaktif menjawab tantangan zaman yang selalu berubah.

Dalam hal ini perguruan tinggi dituntut untuk menghasilkan lulusan yang berkualitas dan bermanfaat ketika lulusan terjun ke masyarakat. Kualitas berhubungan dengan jaminan mutu yang terdapat di perguruan tinggi. Penjaminan mutu di perguruan tinggi sebenarnya merupakan salah satu amanat dari pasal 50 ayat 2, yang menyatakan bahwa pemerintah menentukan kebijakan nasional dan standar nasional pendidikan untuk menjamin mutu pendidikan nasional. ${ }^{1}$

Mutu adalah sebuah hal yang berhubungan dengan gairah dan harga diri. ${ }^{2}$ Bagi setiap institusi, mutu adalah agenda utama dan meningkatkan mutu merupakan tugas yang paling penting. Inilah kenapa di setiap institusi harus mengembangkan sistem jaminan mutu sebagai ciri khas dari institusi tersebut. Peningkatan mutu dalam institusi lembaga pendidikan merupakan hal yang wajib dilakukan.

Penjaminan mutu adalah proses penetapan dan pemenuhan standar mutu secara konsisten dan berkelanjutan sehingga konsumen, produsen, dan pihak lain yang berkepentingan memperoleh kepuasan. Dengan demikian, penjaminan mutu pendidikan tinggi adalah proses penetapan dan pemenuhan

\footnotetext{
${ }^{1}$ Zaenal Arifin, Konsep dan Model Pengembangan Kurikulum (Bandung, PT. Remaja Rosdakarya, 2011), 21.

${ }^{2}$ Edward Sallis, Total Quality Management in Education, terj. Ahmad Ali Riyadi dan Fahrurrozi (Yogyakarta: IRCiSoD, 2010) 29.
} 
standar mutu pengelolaan pendidikan tinggi secara konsisten dan berkelanjutan, sehingga stakeholders memperoleh kepuasan. Pendidikan di perguruan tinggi dikatakan berkualitas atau bermutu apabila mampu menetapkan dan mewujudkan visinya melalui pelaksanaan misinya (aspek deduktif) dan mampu memenuhi kebutuhan stakeholders (aspek induktif), berupa: kebutuhan kemasyarakatan (societal needs), kebutuhan dunia kerja (industrial needs), kebutuhan profesional (professional needs).

Pencapaian tujuan penjaminan mutu melalui kegiatan penjaminan mutu yang dijalankan secara internal oleh perguruan tinggi, akan dikontrol dan diaudit melalui kegiatan akreditasi yang dijalankan oleh BAN-PT atau lembaga lain secara eksternal. Dengan demikian, objektivitas penilaian terhadap pemeliharaan dan peningkatan mutu pendidikan tinggi secara berkelanjutan di suatu perguruan tinggi dapat diwujudkan. Pada dasarnya sistem penjaminan mutu perguruan tinggi di UIN Sunan Kalijaga sudah terlaksana sejak tahun 2006 sampai sekarang. Sasaran mutu yang diinginkan, yaitu: ${ }^{3}$

1. Karya penelitian pendidikan Islam dengan paradigma integratif-interkonekif minimal 50\%

2. Karya ilmiah staf edukatif yang dpublikasikan secara nasional dan internasional minimal sepuluh buah pertahun.

3. Lulusan berkarya di masyarakat sesuai dengan bidang keahlian dalam tahun pertama minimal 70\%

\footnotetext{
${ }^{3}$ Sukiman, Wawancara, Yogyakarta, 27 Desember 2012.
} 
4. Jumlah lulusan tepat waktu studi 8 semester minimal $80 \%$

5. Indeks kinerja dosen (IKD) minimal 3.0 minimal 90\%

6. Lulusan mampu berkomunikasi global dengan TOEFL's score minimal 450 minimal $80 \%$ dan TOAFL's skor minimal 70 skala 100 minimal $80 \%$

7. Lulusan mampu mengaplikasikan teknologi informasi dengan menunjukkan sertifikat minimal nilai " $\mathrm{B}+$ " minimal $80 \%$

Pada dasarnya mutu pendidikan bisa dilihat dari capaian pembelajaran yang sudah dilaksanakan dan diukur oleh lembaga penjaminan mutu perguruan tinggi sesuai dengan capaian mutu atau target mutu yang telah diinginkan oleh pihak Fakultas Tarbiyah dan Keguruan UIN Sunan Kalijaga Yogyakarta.

\section{Konsep Penjaminan Mutu Pendidikan}

Konsep mutu pada dasarnya merupakan konsep yang dikenalkan pada dunia usaha dan industri. Tetapi konsep ini sangat fleksibel untuk diadopsi atau diterapkan pada institusi lain non industri, baik industri besar maupun kecil. ${ }^{4}$ perkembangan konsep mutu terbagi dalam beberapa jenis, yaitu: quality control, quality assurance, dan quality improvement. Ketiga jenis konsep mutu tersebut memiliki hubungan integral sehingga satu dengan yang lainnya memiliki hubungan yang

\footnotetext{
4 Muhammad Faturrohman dan Sulistyorini, Implementasi Manajemen Peningkatan Mutu Pendidikan Islam: Peningkatan Pendidikan Islam Secara Holistik (Yogyakarta: Teras, 2012), 121.
} 
tidak dapat dipisahkan serta saling berkaitan secara berlanjut dalam tahapan pelaksanaan di sebuah sistem institusi. Langkahlangkah proses tersebut dikembangkan dan menjadi sebuah konsep manajemen yaitu manajemen mutu terpadu (TQM). Berikut ini uraian singkat mengenai tiga jenis konsep mutu tersebut, antara lain: ${ }^{5}$

\section{Quality Control}

Quality control (kontrol mutu) merupakan konsep mutu paling tua. Quality control merupakan proses deteksi dan eliminasi komponen dan produk yang tidak sesuai dengan standar dari institusi yang dilakukan pada pasca produksi. Inpeksi dan pemeliharaan adalah metode umum dari kontrol mutu. Quality control merupakan proses yang menjamin bahwa hanya produk yang memenuhi spesifikasi produsen yang dapat keluar ke pelanggan di era industri massal. Quality control merupakan proses pasca produksi yang biasanya dilakukan bukan oleh orang penghasil produksi tersebut.

\section{Quality Assurance}

Quality assurance merupakan pengembangan dari konsep quality control. Pemenuhan spesifikasi produk secara konsisten yang selalu baik sejak awal (right first time every time). Quality assurance lebih menekankan tanggung jawab tenaga kerja dibandingkan inpeksi kontrol mutu. Tujuannya menciptakan produk tanpa cacat (zero

5 Sallis, Total Quality, 58. 
depect/Plihip B.Crosby). Mutu produk yang baik dijamin oleh sistem jaminan mutu yang memposisikan secara tepat bagaimana produksi seharusnya berperan sesuai dengan standar mutu yang diatur oleh prosedur-prosedur yang ada dalam sistem jaminan mutu. Secara umum yang dimaksud dengan penjaminan mutu (quality assurance) adalah proses penetapan dan pemenuhan standar mutu proses secara konsisten dan berkelanjutan, sehingga konsumen, produsen, dan pihak lain yang berkepentingan memperoleh kepuasan. Menurut definisi di ISO 9000:2000 (QMS-Fundamentals and Vocabulary), adalah sebagai berikut : "Quality assurance part of quality management focused on providing confidence that quality requirements will be fulfilled". Secara singkat dapat dipahami quality assurance terfokus pada pemberian jaminan/keyakinan bahwa persyaratan mutu akan dapat dipenuhi. Sementara quality control tugasnya melakukan inspection berdasarkan prosedur yang dibuat dan disahkan oleh quality assurance.

\section{Quality Improvement}

Proses yang baik adalah sebuah proses yang berorientasi terhadap upaya peningkatan mutu ( quality improvement ) untuk memenuhi harapan atau kepuasan pelanggan. Mutu itu dinamis, upaya peningkatan mutu tidak pernah berhenti tetapi selalu berkelanjutan sesuai dengan perkembangan iptek, tatanan nilai dan tuntutan masyarakat serta 
lingkungannya, agar dapat tetap eksis dalam persaingan global. Proses peningkatan mutu ( quality improvement) adalah mengidentifikasi indikator mutu dalam proses, memonitor indikator tersebut dan mengukur hasil dari indikator mutu tersebut yang tentunya mengarah pada outcome, serta selalu berfokus dalam rangka peningkatan proses, sehinga tingkat mutu dari hasil yang dicapai akan meningkat. Tentunya upaya peningkatan mutu (quality improvement ) dilakukan dengan terlebih dahulu diawali dari jaminan mutu (quality assurance), kemudian mengarah pada peningkatan mutu yang proaktif. Hal penting yang menjadi sebuah catatan adalah mutu yang rendah masih dapat kita tingkatkan bila kita berkehendak untuk melakukannya dengan melakukan peningkatan mutu (quality improvement).

Teori ini berangkat dari sebuah pendekatan dalam mengembangkan suatu institusi, lembaga, atau perusahaan yaitu, Total Quality Managemen (TQM). Bisa dikatakan teori ini merupakan bagian dari TQM yang berfokus pada proses berlangsungnya suatu kegiatan. Mutu adalah agenda utama dan meningkatkan mutu merupakan tugas yang paling penting. ${ }^{6}$ Walaupun demikian masih ada sebagian orang yang menganggap kalau mutu sebagai sebuah konsep yang penuh dengan teka teki. Maksudnya adalah bahwa mutu dianggap sebagai suatu hal yang membingungkan dan sulit untuk diukur.

\footnotetext{
${ }^{6}$ Sallis. Total Quality, 58.
} 
Sesuai uraian sebelumnya, sistem manajemen mutu pendidikan merupakan bagian dari sistem manajemen satuan pendidikan, sehingga secara umum berupa siklus plan, implement, assess, dan improve atau PDCA (plan, check, do, action). Substansi utama SPM pendidikan dilaksanakan dengan pendekatan siklus PDCA (Plan - Do - Check - Action) pada proses penyelenggaraan pendidikan.

1. Perencanaan Mutu (plan)

Plan, adanya perencanaan berkaitan dengan perencanaan mutu, meliputi penetapan kebijakan mutu, penetapan tujuan mutu beserta indikator pencapaiannya, serta penetapan prosedur untuk pencapaian tujuan mutu.

2. Pelaksanaan $(d o)$

Do, adanya pelaksanaan dari apa yang sudah direncanakan. Maka untuk menjamin mutu pendidikan, seluruh proses pendidikan, termasuk pelayanan administrasi pendidikan dilaksanakan sesuai dengan SOP yang telah ditentukan.

3. Evaluasi (check)

Adanya monitoring, pemeriksaan, pengukuran dan evaluasi terhadap pelaksanaan dan hasil pelasanaan termasuk audit mutu internal.

4. Tindakan (action), adanya tindak lanjut dan perbaikan dari hasil evaluasi. Menyusun rencana perbaikan dan menyusun laporan pelaksanaan program pendidikan. 


\section{Metode Penelitian}

Dalam rangka memperoleh kajian yang dapat dipertanggungjawabkan secara ilmiah, maka metode penelitian menggunakan metode kualitatif, yang menempatkan peneliti sebagai instrumen utama dalam proses penelitian. Pendeskripsian akan dilakukan secara holistik atau menyeluruh untuk kelengkapan data.

Teknik pengumpulan data primer melalui wawancara mendalam berdasarkan pedoman wawancara kepada responden dan informan yang terkait dalam penelitian ini, yaitu: Ketua dan Staf Penjaminan Mutu Perguruan Tinggi UIN Sunan Kalijaga kemudian dilanjutkan pada Dekan, Staf, dan karyawan Fakultas Tarbiyah dan Keguruan UIN Sunan Kalijaga. Pemilihan lokasi ini didasarkan pada pertimbangan bahwa perguruan tinggi ini memiliki sistem penjaminan mutu yang bisa dibilang bagus dalam pelaksanaannya.

\section{Pencapaian Mutu Fakultas Ilmu Tarbiyah dan Keguruan UIN Sunan Kalijaga}

Kegiatan penjaminan mutu di perguruan tinggi merupakan strategi Direktorat Jendral Pendidikan Tinggi untuk meningkatkan kualitas perguruan tinggi di Indonesia sebagaimana tertuang dalam Higher Education Long Term Strategy (HELTS) 2003-2010 dalam Rinda bahwa, Penjaminan mutu pendidikan tinggi di perguruan tinggi adalah proses penerapan dan pemenuhan standa mutu pengelolaan dan 
pendidikan tinggi secara konsisten dan berkelanjutan, sehingga stakeholder (mahasiswa, orang tua, dunia kerja, pemerintah, dosen, tenaga penunjang, serta pihak lain yang berkepentingaan) memperoleh kepuasan. ${ }^{7}$

Dengan demikian, penjaminan mutu diharapkan dapat dilakukan di seluruh perguruan tinggi dengan memperhatikan butir-butir mutu yang ditetapkan, antara lain: kurikulum program studi, sumber daya manusia (dosen dan tenaga penunjang), mahasiswa, proses pembelajaran, sarana dan prasarana, suasana akademik, keuangan, penelitian dan publikasi, pengabdian masyarakat, tata pamong, manajemen lembaga, sistem informasi, kerjasama dalam dan luar negeri.

Kegiatan penjaminan mutu perguruan tinggi dilaksanakan dalam sebuah sistem yang disebut Sistem Penjaminan Mutu Perguruan Tinggi (SPM- PT), yang terdiri atas: penjaminan mutu yang dilaksanakan secara sistemik oleh perguruan tinggi sendiri (internally driven) yang disebut sebagai Sistem Penjaminan Mutu Internal (SPMI) dan penjaminan mutu yang dilaksanakan oleh badan/lembaga di luar perguruan tinggi yang disebut sebagai Sistem Penjaminan Mutu Eksternal (SPME).

Badan atau lembaga di luar perguruan tinggi yang melaksanakan SPME dapat berasas nasional ataupun internasional dengan syarat diakui oleh Pemerintah. SPME dikenal sebagai akreditasi, yang untuk saat ini pada aras nasional

7 Hedwing Rinda, Sistem Penjaminan Mutu di Perguruan Tinggi Monitoring \& Evaluasi Internal, (Yogyakarta: Graha Ilmu, 2007), 1-2. 
dijalankan oleh Badan Akreditasi Nasional Perguruan Tinggi (BAN- PT). Untuk menjawab keterhambatan sasaran mutu di Fakultas Ilmu tarbiyah dan keguruan ini penulis menggunakan sebuah pendekatan yang digunakan oleh UPM tingkat Universitas dalam Audit Mutu Internal (AMI) setiap tahunnya yaitu menggunkan prosedur monitoring dan evaluasi. Berikut ini prosedur yang harus dilaksanakan dalam evaluasi dan monitoring adalah sebagai berikut: ${ }^{8}$

1. Kegiatan monitoring dan evaluasi dilaksanakan 6 (enam) bulan sekali. Quality Assurance Center (QAC: unit penjaminan mutu pada tingkat universitas) bertanggung jawab untuk mengkordinir kegiatan tersebut.

2. QAC menyusun rencana tahunan monitoring dan evaluasi

3. Paling lambat 2 (dua) minggu sebelum pelaksanaan monitoring dan evaluasi QAC melakukan penjadwalan dan diumumkan serta didistribusikan kepada semua departemen/ unit/ biro/ UPT.

4. QAC menentukan anggota tim monitoring dan evaluasi untuk melaksanakan kegiatan. Nama anggota tim ditunjuk dan dicatat dalam jadwal pelaksanaan monitoring dan evaluasi.

5. Anggota tim yang ditunjuk tidak boleh memiliki keterkaitan tanggung jawab dengan lingkup prosedur yang diaudit. Anggota tim yang ditunjuk adalah yang sudah pernah mengikuti pelatihan monitoring dan evaluasi dan

\footnotetext{
${ }^{8}$ Rinda, Sistem Penjaminan Mutu, 6-8
} 
diberikan SK oleh Rektor untuk satu (satu) periode monitoring dan evaluasi.

6. Anggota tim monitoring dan evaluasi/ auditee yang berhalangan pada waktu kegiatan yang telah ditentukan harus mengkonfirmasikan waktu pengganti pada QAC maupun kepada auditeel anggota tim monitoring dan evaluasi.

7. Anggota tim monitoring dan evaluasi yang ditunjuk segera menyiapkan daftar pertanyaan berdasarkan

a. Dokumen yang terkait dengan proses yang akan diperiks

b. Temuan pemeriksaan sebelumnya

8. Menjelang pelaksanaan kegiatan monitoring dan evaluasi, QAC mengkoordinasikan rapat pembukaan yang dihadiri oleh QAC, anggota tim monitoring dan evaluasi dan auditee.

9. Kegiatan monitoring dan evaluasi dilakukan dengan memeriksa bukti penerapan sistem penjaminan mutu telah dilaksanakan dengan baik.

10. Bila penerapan sistem penjaminan mutu oleh auditee sudah sesuai sebagaimana yang ditentukan dalam dokumen sistem mutu (prosedur kerja, intruksi kerja, catatan mutu), maka selanjutnya temuan diklasifikasikan sebagai berikut:

a. Observasi: Bila diperlukan peningkatan atas penerapan sistem penjaminan mutu yang 
sudah dilaksanakan oleh auditee, atau hasil pengamatan umum terhadap cara kerja auditee.

b. Minor : Bila penerapan sistem penjaminan mutu oleh auditee belum (menyimpang) dengan ketentuan yang ada dalam dokumen sistem mutu, sesuai ketidaksesuaian yang ditemukan dapat segera diperbaiki, dan/ tidak merugikan pelanggan.

c. Major : Bila auditee tidak melaksanakan/ menerapkan sistem penjaminan mutu sebagaimana ditentukan dalam dokumen sistem penjaminan mutu.

11. Anggota tim monitoring dan evaluasi membuat laporan tertulis atas hasil pemeriksaan.

12. Hasil pemeriksaan tersebut akan terkirim langsung ke QAC untuk mendapatkan persetujuan QAC. Setelah disetujui oleh QAC, temuan hasil pemeriksaan akan dikirim ke auditee untuk diisikan rencana tindakan/ pencegahan yang akan dilakukan auditee.

13. Bila temuan tidak dapat segera diperbaiki karena berkaitan dengan kebijaksanaan institusi maka auditee dengan sepengetahuan departemen/ unit/ biro/ UPT terkait harus menginformasikan temuan hasil pemeriksaan tersebut kepada QAC untuk dibawakan dalam Rapat Tinjauan Manajemen (RTM) terdekat. 
14. Pemeriksaan hasil perbaikan harus dilakukan oleh tim monitoring dan evaluasi yang ditunjuk oleh QAC.

15. Hasil pemeriksaan perbaikan harus dicatat oleh anggota tim monitoring dan evaluasi pada kolom laporan verifikasi hasil perbaikan yang sudah disediakan.

16. QAC melaporkan hasil pelaksanaan kegiatan monitoring dan evaluasi dalam RTM yang terdekat waktu pelaksanaannya.

17. Monitoring dan evaluasi add- hoc dapat dilaksanakan di luar rencana tahunan bila;

a. Karena suatu hal, dipandang perlu olehQAC dan

b. Untuk persiapan meta evaluasi (Badan Akreditasi, Badan Registrasi, dan lain-lain)

18. Apabila pelaksanaan/ laporan monitoring dan evaluasi dianggap kurang memuaskan maka QAC berwenang untuk melakukan kegiatan monitoring dan evaluasi ulang.

19. Apabila terdapat perselisihan pendapat dalam penentuan jenis temuan tim monitoring dan evaluasi dengan auditee maka keputusan akhir diambil oleh QAC.

Di atas merupakan prosedur yang dijadikan penulis untuk mengidentifikasi dan pengamatan keterhambatan sasaran mutu pada Fakultas Ilmu Tarbiyah dan Keguruan. Kemajuan dalam target mutu dipengaruhi oleh upaya yang dilakukan oleh pihak Fakultas Ilmu Tarbiyah dan Keguruan. Motivasi sangat penting bagi manajer untuk meningkatkan kinerja (performance) bawahannya karena kinerja tergantung dari motivasi, 
kemampuan, dan lingkungan. ${ }^{9}$

Setiap tahun kami menyiapkan penelitian pendidikan islam dengan paradigm integrati interkonekif dan mendapatkan reward dan pelatihan dosen untuk meningkatkan kualitas dosen. ${ }^{10}$

Oleh karena itu, SM 1 ini sudah mencapai sasaran hanya saja tidak sebanding dengan jumlah dosen di UIN Sunan Kalijaga sebanyak 500, sehingga 10/500 persentasenya sebenarnya sangat kecil hanya $0,02(2 \%)$ jadi perlu ditingkatkan menjadi dua puluh (20) buah. Selanjutnya adalah terkait dengan lulusan berkarya di masyarakat sesuai dengan bidang keahlian dalam tahun pertama minimal $70 \%$. Seperti pada tabel di bawah ini yang diperoleh penulis dari hasil laporan UPM pada tahun 2012:

Tabel 1: Laporan UPM 2012

\begin{tabular}{|c|c|c|c|c|c|}
\hline \multirow{2}{*}{$\begin{array}{c}\text { Periode } \\
\text { Wisuda }\end{array}$} & \multirow{2}{*}{ Jumlah } & \multicolumn{4}{|c|}{ Pernyataan } \\
\cline { 3 - 6 } Wisudawan & $\begin{array}{c}\text { Sangat } \\
\text { Sesuai }\end{array}$ & Sesuai & $\begin{array}{c}\text { Kurang } \\
\text { Sesuai }\end{array}$ & $\begin{array}{c}\text { Tidak } \\
\text { Sesuai }\end{array}$ \\
\hline $\begin{array}{c}\text { Periode II } \\
\text { TA } \\
2010 / 2011\end{array}$ & 6 & 67,7 & 32,3 & 0 & 0 \\
\hline $\begin{array}{c}\text { Periode III } \\
\text { TA } \\
2010 / 2011\end{array}$ & 698 & 19,9 & 51,5 & 28,6 & 0 \\
\hline $\begin{array}{c}\text { Periode I } \\
\text { TA } \\
2011 / 2012\end{array}$ & 609 & 17,2 & 46,4 & 36,4 & 0 \\
\hline Total & 1313 & 34,93 & 43,40 & 21,67 & 0,00 \\
\hline
\end{tabular}

Hasil pengukuran yang sudah dilakukan pada tabel di atas

\footnotetext{
${ }^{9}$ Husaini Usman, Manajemen: Teori Praktik \& Riset Pendidikan (Jakarta: Bumi Aksara, 2008), 250

${ }^{10}$ Sabarudin, Wawancara, Yogyakarta, 24 Juni 2013.
} 
hanya terbatas pada hasil pooling/survei yang diperoleh dari website tracer alumni dan ini sebenarnya belum mencerminkan secara konkret ketercapaian SM 3. O leh karena itu, untuk mengukur SM 3 ini perlu dukungan dari pihak-pihak terkait untuk melakukan tracer study.

Memang sulit mengukur lulusan Fakultas Tarbiyah dan Keguruan yang sudah berkarya di masyarakat, semua itu dikarenakan lulusan atau alumni berasal dari berbagai wilayah.

Memang sudah ada sebuah organisasi setiap wilayah akan tetapi komunikasi yang kurang yang akhirnya dari pihak fakultas belum bisa membaca secara menyeluruh apakah dari lulusan sudah berkarya di masyarakat sesuai bidangnya atau belum. Semua itu terkait dengan belum adanya manajemen alumni dan kurang efektifnya ikatan alumni setiap wilayah. ${ }^{11}$

Dampaknya adalah tidak adanya informasi yang pasti terkait dengan lulusan yang sudah berkarya di masyarakat, ditambah lagi lulusan berasal dari berbagai wilayah.

Tujuan dan manfaat komunikasi adalah sebagai sarana untuk: (1). Meningkatkan kemampuan Manajerial dan hubungan sosial; (2). Menyampaikan dan menerima Informasi; (3). Menyampaikan dan menjawab pertanyaan; (4). Mengubah perilaku (pola pikir, perasaan, dan tindakan) melalui perencanaan, pengorganisasian, pengarahan, dan pengawasan; (5). Mengubah keadaan sosial; (6). Dua hal yang dapat mengubah perilaku dan keadaan sosial adalah komunikasi dan pengambilan keputusan.

${ }^{11}$ Sabarudin, Wawancara, Yogyakarta, 24 Juni 2013. 
Berkarya di masyarakat tidaklah harus masuk dalam institusi pendidikan misalnya mengajar TPQ atau TPA di wilayahnya masing- masing itu sudah termasuk berkarya di masyarakat. ${ }^{12}$

Sasaran mutu selanjutnya adalah jumlah lulusan tepat waktu studi 8 semester minimal $80 \%$. Dari data yang diperoleh oleh penulis terhambatnya SM 4 adalah berhubungan dengan penerapan kurikulum pembelajaran yang dilaksanakan oleh fakultas. Pada saat semester akhir seharusnya mahasiswa hanya mengambil mata kuliah skripsi.

Seharusnya semester akhir mahasiswa input skripsi saja jadi mahasiswa bisa konsentrasi mengerjakan skripsi tidak terpecah- pecah dengan yang lainnya. ${ }^{13}$

Dalam suatu proses pembelajaran, terdapat beberapa komponen yang satu sama lain saling berinteraksi dan berinterrelasi. Komponen tersebut adalah dosen, mahasiswa, tujuan pembelajaran, materi pembelajaran, metode atau strategi pembelajaran. Agar komponen di dalam proses pembelajaran tersebut dapat mencapai keberhasilan dalam implementasinya maka perlu dirumuskan dan ditetapkan standar mutu perguruan tinggi sesuai dengan visi dan misi yang telah ditentukan. Pihak fakultas mempunyai syarat dan prosedur pengajuan skripsi, yaitu: telah menyelesaikan minimal 100 sks, nilai C - ke bawah sebanyak-banyaknya 3 (tiga) mata kuliah, tidak ada nilai E, Skor TO EFL's minimal 400.

Dilihat dari syarat tersebut mahasiswa masih terhambat

\footnotetext{
${ }^{12}$ Sukiman, Wawancara, Yogyakarta, 2 Juli 2013.

${ }^{13}$ Munawar Khalil, Wawancara, Yogyakarta, 27 Desember 2012
} 
oleh beberapa tanggungan mata kuliah karena mengulang mata kuliah semester sebelumnya dan akhirnya mengulang semester depan atau terdapat kegiatan lain yang akhirnya mahasiswa nambah semster. Tidah hanya terkait dengan tangggungan mata kuliah pada semester sebelumnya tetap terkait dengan TOEFL's skor harus 400.

Untuk TO EFL's mahasiswa harus mengikuti ujian di laboratorium bahasa. Menjadi permasalahan lagi adalah jadwal dan kurikulum pembelajaran di Fakultas Ilmu Tarbiyah dan Keguruan itu sendiri. Mahasiswa pada saat belajar di bangku perkuliahan tidak diajarkan terkait dengan TOEFL's dan bertemu dengan mata kuliah bahasa Inggris hanya beberapa kali saja. Selanjutnya beberapa indikasi kenapa mahasiswa menambah semester yaitu terkait dengan pelaksanan kurikulum dan pelatihan pengembangan mahasiswa.

Kendala itu pasti ada mas pertama, kulyah itu hanya memepelajari bahasa dasar bukan TOAFL's dan yang dinginkan adalah TOAFL's dan kedua mahasiswa suka yang mepet-mepet dikarnakan jadwal yang sangat lama. Sebenarnya sudah ada pelatihan bahasa yang dilakukan oleh lembaga pusat bahasa tetapi sepertinya juga kurang maksimal. ${ }^{14}$

Sasaran mutu selanjutnya adalah lulusan mampu berkomunikasi global dengan TO EFL's score minimal 450 minimal 80\% dan TOAFL's skor minimal 70 skala 100 minimal $80 \%$. Sasaran mutu ini memang sudah terlaksana akan tetapi terdapat beberapa permasalahan komunikasi antar lembaga.

\footnotetext{
${ }^{14}$ Sukiman, Wawancara, Yogyakarta, 2 Juli 2013.
} 
Keadaan ini terjadi karena jadwal dari masing- masing lembaga tersebut berbeda dan kemungkinan terjadi benturan jadwal yang akhirnya mahasiswa tidak biasa melaksanakan kegiatan yang berhubungan dengan bahasa.

Untuk pengajuan skripsi salah satunya adalah menyertakan sertivikat TOEFL's yang scorenya adalah \pm 400 kalau belum mencapai itu brarti masih belum bisa diterima pengajuan proposalnya. ${ }^{15}$

Skor TOEFl's dan syarat-syarat yang lain yang ditentukan oleh fakultas merupakan standar mutu. Standar mutu ini disusun berdasarkan ketentuan normatif peraturan perundangan, visi dan misi perguruan tinggi, serta kebutuhan pengguna terutama tentang kualitas lulusan agar memenuhi kompetensi yang diperlukan oleh pengguna lulusan. ${ }^{16}$

Dalam hal ini mahasiswa mengikuti tes TOEFL's dan TOAFL's. Dua tes tersebut dijadikan syarat pengajuan seminar proposal skripsi dalam tingkat fakultas. Fakultas Tarbiyah mempunyai standarisasi skor TOEFL's yang menjadi sarat ketrimanya proposal skripsi yang nantinya akan diajukan yatu \pm 400 kurang dari itu maka mahasiswa belum bisa mengajukan proposal skripsi.

Sasaran mutu selanjutnya adalah lulusan mampu mengaplikasikan teknologi informasi dengan menunjukkan sertifikat minimal nilai "B+" minimal $80 \%$. Sasaran mutu ini berhubungan dengan kewajiban mengikuti Program Pelatihan

${ }^{15}$ Sukiman, Wawancara, Yogyakarta, 12 Juli 2013.

16 Direktorat Jenderal Pendidikan Tinggi, Sistem Penjaminan Mutu Perguruan Tinggi (SPM-PT). (Jakarta: Dirjen Dikti, 2010), 18-20. 
Bahasa, Teknologi infomasi (IT) dan Program Pengembangan Kepribadian Integral dan Berkelanjutan.

Setiap mahasiswa wajib mengikuti program pelatihan bahasa, program pelatihan IT dan program pengembangan kepribadian integral dan berkelanjutan. Bukti telah mengikuti program menjadi syarat mengikuti munaqasah dan khusus untuk tahsin al-Quran menjadi syarat mengikuti PPL. ${ }^{17}$

Kegiatan penjaminan mutu perguruan tinggi harus didukung oleh ketersediaan data dan informasi tentang perguruan tinggi secara akurat, lengkap, dan mutakhir. Data dan informasi tersebut dikelola oleh suatu pangkalan data pada masing- masing perguruan tinggi. Semua itu yang dipaparkan di atas berhubungan dengan tujuan Sistem Penjaminan Internal (SPMI), yaitu: bertujuan memelihara dan meningkatkan mutu pendidikan tinggi secara berkelanjutan yang dijalankan oleh suatu perguruan tinggi secara internal, untuk mewujudkan visi serta untuk memenuhi kebutuhan stakeholders melalui penyelenggaraan Tridharma Perguruan Tinggi. ${ }^{18}$

\section{Pelaksanaan Sistem Penjaminan Mutu Perguruan Tinggi pada Fakultas Tarbiyah dan Keguruan UIN Sunan Kalijaga.}

Pelaksanaan penjaminan mutu di UIN Sunan Kalijaga Yogyakarta mengacu pada pendekatan siklus Plan - Do - Check

17 Fakultas Tarbiyah dan Keguruan. Buku Panduan Akademik (Yogyakarta: FITK UIN Sunan Kalijaga, 2012), 17.

${ }^{18}$ Fakultas Tarbiyah dan Keguruan. Buku Panduan, 17. 
- Action (PDCA) sebagai berikut: ${ }^{19}$

1. Perencanaan Mutu(Plan)

Di dalam perancanaan mutu terdapat kebijakan mutu, penetapan tujuan mutu beserta indikator pencapaiannya, serta penetapan prosedur untuk pencapaian tujuan mutu. Terdapat kebijakan mutu di Fakultas Tarbiyah dan Keguruan UIN Sunan Kalijaga yaitu: Fakultas Tarbiyah dan Keguruan sebagai fakultas yang unggul dan terkemuka menghasilkan lulusan yang mempunyai kemampuan mengintegrasikan pendidikan Islam dan keilmuan bagi peradaban yang selanjutnya dituangkan ke dalam visi dan misi Fakultas Tarbiyah dan Keguruan.

2. Pelaksanaan $(D o)$

Mekanisme pelaksanaan sistem penjaminan mutu perguruan tinggi pada sebuah perguruan tinggi tidak terdapat pola buku panduan dari pusat (DIKTI) dan harus diikuti oleh perguruan tinggi. Pengorganisasian penjaminan mutu di suatu perguruan tinggi sangat bergantung pada ukuran, struktur, sumber daya, visi dan misi, sejarah dan kepemimpinan dari perguruan tinggi tersebut.

Perguruan tinggi dapat mengadakan unit penjaminan mutu (UPM) di dalam struktur organisasinya yang dipimpin oleh seorang wakil rektor, atau suatu unit

${ }^{19}$ Fakultas Tarbiyah dan Keguruan. Buku Panduan, 53 
independen yang terlepas dari struktur organisasi yang dipimpin oleh seorang dosen. Sebagai contoh yang diterapkan pada UIN Sunan Kalijaga pada saat ini.

Secara garis besar yang diamati oleh peneliti yaitu pelaksanaan sistem penjaminan mutu di Fakultas Tarbiyah dan Keguruan UIN Sunan Kalijaga bersifat disentralistik, yaitu memusat pada Universitas. Di mana semua kebijakan tentang penjaminan mutu terpusat universitas (Unit Penjamina Mutu (UPM)).

Akan tetapi setiap fakultas mempunyai hak dalam mengembangkan atau memfokuskan target mutu yang nantinya yang menjadi ciri khas dari setiap fakultas. Seperti jurusan Pendidikan Bahasa Arab (PBA) memfokuskan pada bahasa Arabnya begitupun pada fakultas lain.

Pada prakteknya setiap fakultas mempunyai perwakilan dari UPM. Secara tidak langsung fungsi dari perwakilan setiap fakultas melaporkan permasalahanpermasalah yang dihadapi fakultas yang seterusnya dilaporkan ke UPM yang selanjutnya akan diselesaikan dan dievaluasi. Secara tidak langsung perwakilan setiap fakultas bertugas sebagai seorang yang memonitoring pelaksanaan kebijakan penjaminan di setiap fakultas.

Pelaporan dari setiap perwakilan dari fakultas dilaksanakan seminggu sekali yaitu pada hari kamis. Di hari tersebut maka akan dibahas permasalahan yang 
terdapaat di setiap fakultas.

Dari kebijakan mutu yang sudah dipaparakan di atas dalam tingkat universitas dijabarkan oleh fakultas untuk tersendiri untuk menghasilkan pencapaian mutu yang diinginkan sesuai dengan visi dan misi Fakultas Ilmu tarbiyah dan keguruan UIN Sunan Kalijaga. Penjabaran yang dilaksanakan tidak melepas dari kebijakan atau sasaran mutu dari universitas.

Di atas merupakan proses dan prosedur untuk mencapai sasaran mutu yang diinginkan dari kebijakan mutu UIN Sunan Kalijaga. Dari upaya yang dilaksanakan akan menghasilkan sasaran mutu yang diinginkan dari Fakultas Tarbiyah dan Keguruaan UIN sunan Kalijaga sesuai dengan misi dan visinya.

3. Evaluasi (Check)

Evaluasi di sini ada beberapa tingkatan yang pertama adalah tingkat universitas dan tingkat fakultas. Monitoring yang dilaksanakan pada evaluasi ini adalah UPM mempunyai utusan di setiap fakultas. Secara tidak langsung fungsi dari perwakilan tersebut melaporkan permasalahan- permasalah yang dihadapi fakultas yang selanjutnya akan diselesaikan dan dievaluasi dalam tingkat universitas.

Secara tidak langsung perwakilan setiap fakultas bertugas sebagai seorang yang memonitoring pelaksanaan kebijakan penjaminan di setiap fakultas. Setiap fakultas 
melaksanakan audit hampir sama dengan pelaksanaan audit pada universitas.

Kami (Staf UPM) mempunyai utusan di setiap fakultas yang mewakili kegiatan kami. Evaluasi dalam UPM dilaksanakan setiap hari kamis, yang di dalamnya membahas pelaksanaan penjaminan mutu dalam tingkat fakultas dan permasalahan-permasalahan yang ada dan audit yang dilakukan selama setahun dua kali. ${ }^{20}$

Ada beberapa kegiatan evaluasi yang dilaksanakan di Fakultas Tarbiyah dan Keguruan, yaitu:

a. Rapat evaluasi pimpinan fakultas dan jurusan dilaksanakan setiap hari senin.

b. Rapat koordinasi yang dilakukan pada awal semester, tengah semester dan akhir semester

c. Rapat koordinasi menjelang akhir semester yaitu rapat proses akhir semester

Di fakultas tarbiyah dan keguruan mempunyai sistem evaluasi. Yang pertama evaluasi yang dilakukan oleh pimpinan (fakultas) mulai dari dekan, pudek I, pudek II, pudek III dan setiap kepala jurusan. Di dalam evaluasi ini membahas berbagai permasalahan mulai dari mahasiswa akademik dan apapun yang berhubungan dengan fakultas besertakan evaluasinya. Yang kedua rapat yang melibatkan dosen di setiap jurusan, rapat ini dilaksanakan maksimal sampai tiga kali. (1). Rapat koordinasi awal semester membahas tentang pembuatan silabus, RPP dan lain-lain. (2). Rapat menjelang ujian tengah semester.

${ }^{20}$ Epha, Wawancara, Yogyakarta, 7 Mei 2013. 
(3). Rapat koordinasi menjelang ujian akhir semester. Selanjutnya evaluasi yang dalam fakultas yang melibatkan seluruh dosen yang dinamakan evaluasi proses akhir semester. ${ }^{21}$

Berangkat dari evaluasi dan rapat koordinasi yang dilaksanakan di atas maka akan dijadikan bahan untuk pengembangan pada semester selanjutnya. Terkait dengan program pengembangan di fakultas tarbiyah dan keguruan. Apabila program dikaitkan dengan evaluasi program maka program didefinisikan sebagai suatu unit atau kesatuan kegiatan yang merupakan realisasi dari suatu kebijakan, berlangsung dalam proses berkesinambungan dan terjadi dalam suatu organisasi yang melibatkan sekelompok orang. Ada tiga pengertian penting dalam penentuan program, yaitu (1) realisasi atau implementasi suatu kebijakan, (2) terjadi dalam waktu relatif lama atau berkesinambungan, (3) terjadi dalam organisasi yang melibatkan sekelompokorang. ${ }^{22}$

Evaluasi program adalah proses untuk mengetahui apakah tujuan pendidikan sudah dapat direalisasikan, termasuk pula sebagai upaya menyediakan informasi untuk disampaikan kepada pengambil program. Evaluasi program mencakup pokok pembahasan yang lebih luas. Cakupan bisa dimulai dari evaluasi kurikulum sampai pada evaluasi program dalam suatu bidang studi. Sesuai

${ }^{21}$ Sukiman, Wawancara, Yogyakarta, 2 Juli 2013.

22 Suharsimi Arikunto, Evaluasi Program Pendidikan (Jakarta: Bumi Aksara, 2009), 3. 
dengan cakupan yang lebih luas maka yang menjadi objek evaluasi program juga dapat bervariasi, termasuk di antaranya kebijakan program, implernentasi program, dan efektifitas progran.Dalam menjalankan suatu proses penjaminan mutu, diperlukan adanya suatu proses evaluasi yang komprehensif dalam bentuk pengauditan. Pengauditan dalam proses penjaminan mutu mencakup beberapa aspek sebagai berikut: ${ }^{23}$

a. Auditing, yaitu cara organisasi untuk mengecek bahwa seluruh prosedur benar-benar dijalankan.

b. Pengecekan yang teratur dilakukan secara sistematis untuk mengidentifikasi apakah prosedur untuk fungsi tertentu dipakai atau tidak.

c. Hal yang diaudit adalah prosedur, bukan orang.

4. Tindakan (Action),

Tindakan yang dilakukan oleh fakultas yang berhubungan dengan mutu dan evaluasinya adalah penyelesaian secara tuntas dan berkelanjutan. Hal ini mengacu pada proses evaluasi dan rapat koordinasi yang dilaksanakan pada Fakultas Tarbiyah dan Keguruan UIN Sunan Kalijaga.

Pengelolaan penjaminan mutu yang diterapkan di Fakultas Tarbiyah dan Keguruan UIN Sunan Kalijaga sudah melaksanakan pengelolaan penjaminan mutu walaupun belum ada pedoman tertulis. Di sini penulis

${ }^{23}$ Arikunto, Evaluasi Program, 194. 
mengidentifikasi dari hasil pengamatan di lapangan. Model pengelolaan penjaminan mutu pendidikan menggunakan pendekatan PDAC yaitu menggunakan proses sirkuler setiapkegiatan sebagaimana berikut: ${ }^{24}$

a. Formulasi kebijakan merupakan tahap penetapan regulasi dan standar penjaminan mutu pendidikan.

b. Implementasi merupakan tahap pelaksanaan standar penjaminan mutu pendidikan.

c. Monitoring dan evaluasi merupakan tahap pengendalian standar penjaminan mutu pendidikan.

d. Rekomendasi merupakan tahap pengembangan standar penjaminan mutu pendidikan.

\section{Penutup}

Penerapan sistem penjaminan mutu dimulai dari visi dan misi lembaga pendidikan yang selanjutnya diturunkan dalam target atau mutu pendidikan dan selanjutnya diturunkan dalam visi dan misi fakultas. Dari visi dan misi fakultas itu nantinya dijadikan bahan yang akan menjadi isi dari kurikulum yang nantinya diterapkan dalam pembelajaran. Dari hasil penerapan tersebut output yang dihasilkan nantinya akan sesuai dengan visi dan misi yang diinginkan oleh lembaga tersebut. Oleh karena itu kualitas pendidikan ditentukan oleh target mutu yang disusun oleh lembaga tersebut.

\footnotetext{
${ }^{24}$ Nanang Fattah, Sistem Penjaminan Mutu Pendidikan (Bandung: PT. Remaja Rosdakarya, 2012), 16.
} 


\section{Daftar Rujukan}

Arifin, Zaenal. Konsep dan Model Pengembangan Kurikulum. Bandung: PT. Remaja Rosdakarya, 2011.

Arikunto, Suharsimi. Evaluasi Program Pendidikan. Jakarta: Bumi Aksara, 2009.

Direktorat Jenderal Pendidikan Tinggi, Sistem Penjaminan Mutu Perguruan Tinggi (SPM-PT). Jakarta: Dirjen Dikti, 2010.

Fakultas Tarbiyah dan Keguruan. Buku Panduan Akademik. Yogyakarta: FITK UIN Sunan Kalijaga, 2012.

Fattah, Nanang. Sistem Penjaminan Mutu Pendidikan. Bandung: PT. Remaja Rosdakarya, 2012.

Faturrohman, Muhammad dan Sulistyorini. Implementasi Manajemen Peningkatan Mutu Pendidikan Islam: Peningkatan Pendidikan Islam Secara Holistik. Yogyakarta: Teras, 2012.

Rinda, Hedwing. Sistem Penjaminan Mutu di Perguruan Tinggi Monitoring \& Evaluasi Internal. Yogyakarta: Graha Ilmu, 2007.

Usman, Husaini. Manajemen: Teori Praktik \& Riset Pendidikan. Jakarta: Bumi Aksara, 2008.

Sallis, Edward. Total Quality Management in Education, terj. Ahmad Ali Riyadi dan Fahrurrozi. Yogyakarta: IRCiSoD, 2010. 